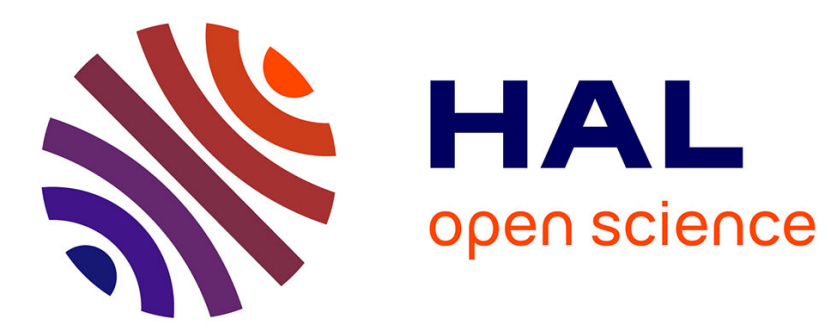

\title{
The Innovation Cycle for Sustainable ICT Education
}

Daniel Burgos

\section{To cite this version:}

Daniel Burgos. The Innovation Cycle for Sustainable ICT Education. 1st International Conference on Sustainable ICT, Education, and Learning (SUZA), Apr 2019, Zanzibar, Tanzania. pp.218-224, 10.1007/978-3-030-28764-1_24. hal-02515727

\section{HAL Id: hal-02515727 \\ https://hal.inria.fr/hal-02515727}

Submitted on 23 Mar 2020

HAL is a multi-disciplinary open access archive for the deposit and dissemination of scientific research documents, whether they are published or not. The documents may come from teaching and research institutions in France or abroad, or from public or private research centers.
L'archive ouverte pluridisciplinaire HAL, est destinée au dépôt et à la diffusion de documents scientifiques de niveau recherche, publiés ou non, émanant des établissements d'enseignement et de recherche français ou étrangers, des laboratoires publics ou privés. 


\title{
The Innovation Cycle for Sustainable ICT Education
}

\author{
Daniel Burgos \\ Research Institute for Innovation \& Technology in Education (UNIR iTED) Universidad \\ Internacional de La Rioja (UNIR), 26006 La Rioja, Spain \\ daniel.burgos@unir.net
}

\begin{abstract}
Usually, the cycle of innovation is sold as a great progress in Education. However, in Education, the cycle of innovation does not exist as we might expect. Innovation is cyclical by itself. Each step of the structure can be modified, improved and complemented without waiting for a whole process that shows logic in other areas (engineering, logistics, and psychology, for instance) but that, in education, seems to be a luxury. This position paper shows why and how to perform a dynamic innovation cycle that enhances learning and teaching experiences, Worldwide, including North-North, North-South and South-South approaches, supported by initiatives by UNESCO, the International Council of Distance Education, Open Education Consortium, the European Commission and others.
\end{abstract}

\section{Innovation cycle and the Sustainable Development Goals}

Our common ground is education. This is stated by the sustainable development goals of the United Nations (SDG). It is the objective 4: quality education.

But the objective 4 is closely linked to other objectives, as the number 2, on eradication of hunger, or number 3 on health, or 8 on decent work and the 16, about peace. Education lives across society as a whole. And education requires innovation. Normally, the innovation is structured as a cycle consisting of 3 pillars: evaluation, quality and training. Personally, I think that there may be more. Each pillar will affect teachers, students, and staff support and management. In addition, innovation itself focuses on the educational system and the educational methodology [1].

\subsection{What innovation means}

In short, what Innovation means? Why someone new at the leading post needs to remodify everything from scratch? Why when a blue guy follows a red one, or the other way around, education is always losing something good? Is that difficult to understand that something can be saved from burning to the ground? [2; 3]

Selective innovation over specific steps of methodology, assessment, training, content authoring or any other links of the chain, is a breakthrough. Simple, effective, encouraging [4]. It means the missing link. We call it transgenic learning (\#transgeniclearning) because it actually follows the same process, metaphorically 
speaking: out of a chain of parts, one specific part is taken, modified, and put back on the chain. To make it better, or faster, or cheaper, or more personalised, or localized, etc.

What we stand for is that the timely application of selective changes might mean a World, and it takes just a moment in the design of a lesson plan. The school teacher of the university professor is entitled to do so, without waiting for an overall regulation.

And nowadays, the real key, the golden rice of Education, that effective move that any docent can make on their own, is to combine regular academic programmes with informal learning. To integrate Open Educational Resources, MOOCs, SPOCs, Learning Objects and so many pieces of knowledge uploaded out there (we call it Internet), into their classroom. The challenge is to select the quality content. But the integration part should be easy. Formal and informal integrated, not that difficult and a huge breakthrough in Education.

\section{What is Transgenic Learning?}

Genetically Modified Organisms (GMO) is a controversial technique to produce new life or food based on the artificial modification of DNA [5; 6]. Induced by an external disruption, a significant change happens, as if it might be part of the natural evolution of a species. In doing so, adaptation is forced into the natural course, so that an additional feature is provided to that species: from a stronger plant against stormy weather or a plague, to a vitamin embedded into a cereal that does not contain it by default, through the modification of a human protein. This external intervention is conflictive from a number of approaches: ethical, scientific, Societal and economic, to name a few. However, the possibility exists; and if smartly applied, it provides the human being with a new resource for progress.

Indeed, genetically modified organisms (GMOs) are those organisms in which the genetic material has been modified through modern technology to produce a new organism or the same one with a modified set of properties [7]. For example, to remove something that does not work or may work better, it is later modified and it is finally reinserted. It is a simple process: choose something that you want to modify, because it does not work, or because we want it to adapt somehow, modified it and reinsert it.

You can choose one that does not work well, which is not well suited, which can be improved, which can be complemented. We can choose, modify it, and reinsert it in the cycle. And all this, without waiting for a semester or a whole year [7; 8]. Innovation can be done immediately. Although there is no support to a lack of planning or an improvisation, a teacher (at school or university, everywhere) should not stand by the imposition of a cycle that is not the reality of their educational context, in the classroom. Innovation should serve as a healthy and continuous process of regeneration and progress. 


\section{A Significant Breakthrough in Education}

Education, as a whole, nowadays, requires a disruptive boost [9; 10]. If we teach and learn in the same way that we did for the last 20 centuries; if we use the very same academic structures that 10 centuries ago; if we stress some methodologies from the early XX century; and if we use resources from before the rise of Internet; if all this happens, we will miss every single possibility that the last 20 years bring to the table. We will miss new, adapted, personalized ways to learn and to teach; to be more efficient, to get a better performance; to enjoy more the experience as a user; and to improve the competence and skill acquisition. Furthermore, we need to break this slow evolution in Education. The youngsters, the technicians, the mass media, the entertainment industry, all of them are far advanced from any practical implementation in the classrooms, from kinder garden to the University.

Open Educational Resources, MOOCs, Virtual Reality, Augmented Reality, Emotional Intelligence, Personalized Learning, Analytics and so many resources, services and approaches to complement, enhanced and evolve Education, as it is now $[11 ; 12]$. We need a radical innovation, to design a new paradigm, to complement the existing ones, to evolve with the actual users of the system (students, teachers, professors, tutors, parents) and not always far behind from them. We need a GMO concept into Learning and teaching, a transgenic approach to Education. Something that makes things evolve quicker and more adapted into a very specific and practical objective. And this is a complex challenge. Compulsory. Needed. Urgent. But a challenge, yet.

And out of this challenge, the most difficult part is to find the right integration between informal ways of learning, teaching and using daily services, with formal courses and academic degrees; the smart combination of resources inside-outside the classroom; the update of accredited content with enriched, additional information outside the official syllabus that can fit into the same slot of educational competences [13; 14].

\section{The Role of ICT in Educational Innovation}

Teachers are in revolution. They claim an active role in new ways of learning and teaching. Usually, through the use of ICT in the classroom, wherever that classroom is, face-to-face or online. They claim, fight for and push for means, time and capacity decision in the innovation cycle in Education. They can be disruptive through the use of Open Educational Resources (OER), live analysis of learner data and, of course, ICT tools in the classroom and long list of activities and services [15].

Literally, this revolution is happening everywhere. We count parallel events in Sidney, Ljubljana, Buenos Aires, Beijing, London, Salamanca, Visakhapatnam, Paris, Toronto, Tallin, Bogotá, and a long list of places. Thousands of school and university teachers want to do better, perform better, support better. They are committed and determined. This is an overall force that requires global awareness and action, National policies, regional contributions, peer-to-peer interaction and a key role from 
every character in the setting: from learners to administrative staff, principals, tutors, parents and sympathizers. And, of course, from the teachers.

In this context, ICT can be the secret ingredient to facilitate that healthy revolution. From a basic use to an advanced tool creation, teachers can integrate communication, interaction, assessment, innovation, content and any other element of any educational cycle. This revolution is very much alive and kicking, and it will bring a real change in Education.

\section{$5 \quad$ OER as a Means to Boost Education}

Which seems clear is that we need an agreement. In OER many issues are at stake yet: accreditation, credit recognition, access, etc. All of them emerge from practice, from the community of practice, from the actual users (i.e. students, teachers, professors, management staff, etc.) We all are very committed to provide an open environment, with the various interpretations of what "open" means. We discuss, design activities, organize congresses, create content, give lectures, write documents about educational policy, review papers, work with Governments and regional departments, publish books and share out thoughts with blog-posts like this one, to name a few actions. Furthermore, we all look for a pro-active, fruitful, interesting and intellectually spicy environment that supports learning, competence building, and integration, along with personal and group development [10].

However, open means also controversy. Nobody argues against the good-willing approach to the various pillars of openness: access, content, data, research results, licensing, policy and technology. However, it seems that open quite often means unregulated. And unregulated might mean whatever. And this should not be the case when we deal with OER. We, the community, must be sure that content, access, technology and the other pillars provide the user with the best quality and, above all, with a minimum threshold for quality.

This approach would require a list of requirements and metrics to meet by every OER to ensure that threshold, based on an agreement amongst the various stakeholders. We need to normalize that approach, to make it sensible, reachable and useful.

Furthermore, we need to get an agreement to make the user feel safe and inside a quality framework, every time that this very user takes an OER. OER must be a seal for quality content and quality education and the OER community can reach a consensus about this basic right.

\subsection{MOOCs, as an example of innovative OER, applied}

Informal learning and social interaction are receiving increasing attention in current eLearning campuses and platforms. Massive Open Online Courses (MOOCs) are no exception [16]. In plain online campuses, students now have a wide range of options for social actions and group collaborations at their disposal: post/answer questions in forums, start their own activities, create their own sites, wikis, invite colleagues, 
comment on someone else's job, score jobs made by others, incorporate external materials to their knowledge repository, fill in questionnaires, participate in WebRTC sessions with teachers, et cetera. Small Private Online Course (SPOCs) and locally deployed Learning Management Systems (LMS) already allow almost endless possibilities in humble environments. These can grow exponentially in an x/c MOOC setting which can potentially manage thousands of learner accounts around common learning material.

\subsection{Open licensing, proprietary content, as an innovative breakthrough}

Nowadays, one key discussion point is about open licensing [12; 17]. The bottom line is that resources created out of public funding should be open and free. This funding comes from tax payers for the greater good and no one could make business or restrict access to these outcomes. This means, for instance, that professors of public universities, being civil servants, develop resources and provide them to the community openly. They keep the intellectual property, but not the exploitation rights or the ownership.

On the other side, when private funding is used to create resources, it depends on the author and-or owner the way to use them and to put them in the market. They can be open or free or universal or nothing at all or a combination of these. This owner has no obligation to make them available to the community as if they were supported by public funding. There is a claim from a section of the OER movement that everything should be open and free ever, no matter who is financially supporting the resource or the educational process. However, a balance should be reached to guarantee the exploitation rights and the sustainability of the creations, when they might come from various sources. Public funding means public resources; but private funding means the need to find an agreement about service and access with the owner.

\section{Conclusions}

There are more parts of this cycle of innovation, such as content, licenses or the exploitation, for example. In theory, the cycle of innovation runs like a clockwork: turns and turns inside out and outside in trying to understand and improve. Sometimes, to give more laps will not a real good and it does not make any progress. Other times, giving turns is like a clock based on a Nautilus shell, as a Fibonacci series, where you get more knowledge and better application after each iteration. However, this is not true.

They have sold us something that is not accurate. Engineers, entrepreneurs and bureaucrats wanted to parameterize a process useful for them. However, it does not provide an additional value to the educational community, if it is not properly contextualised. If we apply the spirit of the full cycle of evaluation we should be using semesters or full years to check whether the measures are useful or not. And so long seems eternal at ICT in Education, where everything changes from one month to the next one. 
The reality is quite different: there is no cycle of innovation in education. We must break it and innovate now, without waiting, hungry for change and improvement. Innovation must be cyclic by itself. And a form of innovation is through "Transgenic learning". It is a metaphor, a simile, only a provocative title to explain an equal transformative reality but much less conflictive than the original term.

In education, the key innovation that will mark an era, the transgenic learning, the disruptive innovation, right now, is the combination of formal education with informal education: How to integrate educational resources outside the official programme with those very programmes. How to take advantage of a permanent connection of a student so that they can learn and practice anywhere at any time. How to use free educational resources as a significant part of the official curricula in primary education, secondary education, high school, University, vocational education, etc.

Albert Einstein said that "The definition of insanity is to do the same thing over and over again and to expect a different result". There is no need to use an industrial cycle of innovation in the educational innovation cycle, which has a very specific profile and needs. We must break the inertia, we must innovate in education, and we must do it now.

\section{Acknowledgement}

This work is supported by the Research Institute for Innovation \& Technology in Education (UNIR iTED, http://ited.unir.net), the UNESCO Chair on eLearning and the ICDE Chair in Open Educational Resources (http://research.unir.net/unesco/), at Universidad Internacional de La Rioja (UNIR, http://www.unir.net).

\section{References}

1. Robert, K. W., Parris, T. M., \& Leiserowitz, A. A. What is sustainable development? Goals, indicators, values, and practice. Environment: science and policy for sustainable development, 47(3) (2005) 8-21

2. EC-European Commission. Opening up Education: Innovative teaching and learning for all through new Technologies and Open Educational Resources. Brussels, Belgium (2013)

3. Berg, B., \& Ostergren, B. Innovations and Innovation Processes in Higher Education (1977)

4. Kleinknecht, A. Innovation patterns in crisis and prosperity: Schumpeter's long cycle reconsidered. Springer (2016)

5. Apolinario, R. M. Genetically Modified Organisms (2015)

6. Burton, M., Rigby, D., Young, T., \& James, S. Consumer attitudes to genetically modified organisms in food in the UK. European Review of Agricultural Economics, 28(4) (2001) 479-498

7. Phillips, T. Genetically modified organisms (GMOs): Transgenic crops and recombinant DNA technology. Nature Education 1(1):213, retrieved June 2nd, 2018, from https://www.nature.com/scitable/topicpage/genetically-modified-organisms-gmostransgenic-crops-and-732 (2008) 
8. Fadeeva, Z., \& Mochizuki, Y. Higher education for today and tomorrow: university appraisal for diversity, innovation and change towards sustainable development. Sustainability Science, 5(2) (2010) 249-256

9. Collins, A., \& Halverson, R. The second educational revolution: Rethinking education in the age of technology. Journal of computer assisted learning, 26(1) (2010) 18-27

10. Wrigley, T. Rethinking education in the era of globalization. Contesting Neoliberal Education : Public Resistance and Collective Advance, (2009) 61-82

11. New Media Consortium, \& EDUCAUSE Learning Initiative. The NMC Horizon Report: 2015 Higher Education Edition. Austin, TX: The New Media Consortium (2015)

12. McGreal, R., Kinuthia, W., Marshall, S., \& McNamara, T. Open educational resources: Innovation, research and practice. Commonwealth of Learning, Vancouver (2013)

13. De-la-Fuente-Valentín, L., Carrasco, A., Konya, K., \& Burgos, D. Emerging technologies landscape on education: A review. IJIMAI, 2(3), 55 (2013)

14. Dabbagh, N., \& Kitsantas, A. Personal Learning Environments, social media, and selfregulated learning: A natural formula for connecting formal and informal learning. The Internet and higher education, 15(1) (2012) 3-8.

15. Meek, V. L., Teichler, U., \& Kearney, M. L. Higher education, research and innovation: Changing dynamics. Kassel: International Centre for Higher Education Research (2009)

16. Bry F., Ebner M., Pohl A., Pardo A., Taraghi B., "Interaction in Massive Courses". Journal of Universal Computer Science, vol. 20 (2014)

17. Weller, M. The battle for open. London: Ubiquity Press. Retrieved from http://www.ubiquitypress.com/site/books/detail/11/battle-for-open/ (2014) 